\title{
COMPARISON OF INHIBITORY ACTIVITY AGAINST THE $\alpha$-GLUCOSIDASE ENZYMES IN THE EXTRACTS AND FRACTIONS FROM LEAVES OF THE GARCINIA KYDIA ROXBURGH
}

\author{
SEPTIANI MARTHA ${ }^{*}{ }^{*}$ BERNA ELYA $^{1 *}$, MUHAMMAD HANAFI $^{2}$ \\ ${ }^{1}$ Department of Pharmacy, Universitas Indonesia, Depok, Indonesia. ${ }^{2}$ Department of Chemistry, Indonesian Institute of Sciences, Serpong, \\ Indonesia. Email: septi4948@yahoo.com/Berna.elya@farmasi.uc.ac.id
}

Received: 17 March 2017, Revised and Accepted: 13 April 2017

\section{ABSTRACT}

Objective: Garcinia kydia Roxb. is a species of the genus Garcinia, is based chemotaxonomic has various bioactive compounds that have been isolated by a variety of pharmacological activities, one of the activities that are being developed that inhibition of $\alpha$-glucosidase. However, $\alpha$-glucosidase inhibitory activity in the extracts and fraction from leaves of the $G$. kydia Roxb. has not been reported. In this study, seeks to evaluate of $\alpha$-glucosidase inhibitory activity against extracts and fractions of potentially.

Methods: The $\alpha$-glucosidase inhibitory activity test conducted by in vitro using the enzymatic reaction is measured of quantity with a microplate reader and identifies the compound from the active fraction with normal-phase thin layer chromatography.

Results: The ethyl acetate and methanol extract have the potential to inhibit the $\alpha$-glucosidase with the percent inhibition at a concentration of $500 \mu \mathrm{g} / \mathrm{ml}$ of $83 \%$ and $59 \%$, respectively. The active fraction of the ethyl acetate extracts (FEA8) with percentage inhibition at concentrations of $100 \mu \mathrm{g} / \mathrm{ml}$ and inhibitory concentration ( $\mathrm{IC}_{50}$ ) values of $80 \%$ and $2.79 \mu \mathrm{g} / \mathrm{ml}$, respectively, and active fraction of the methanol extracts (FMT3) with percent inhibition at concentrations of $100 \mu \mathrm{g} / \mathrm{ml}$ and $\mathrm{IC}_{50}$ values of $71 \%$ and $8.43 \mu \mathrm{g} / \mathrm{ml}$, respectively.

Conclusion: G. kydia Roxb. evident has the potential to inhibit the $\alpha$-glucosidase. Flavonoid and phenolic compounds that suspected of acts as $\alpha$-glucosidase inhibitory activity. Thus, the research will continue the process of isolating the active compound so that it can be developed as natural therapeutic agents in the control of glucose.

Keywords: Garcinia kydia Roxburgh, $\alpha$-glucosidase inhibitory activity, Antidiabetic, In vitro.

(c) 2017 The Authors. Published by Innovare Academic Sciences Pvt Ltd. This is an open access article under the CC BY license (http://creativecommons. org/licenses/by/4. 0/) DOI: http://dx.doi.org/10.22159/ajpcr.2017.v10i7.18529

\section{INTRODUCTION}

The genus Garcinia has various bioactive compounds have been isolated which is polyisoprenylated benzophenone derivatives, xanthine derivatives, biflavonoid, and terpenoids with variety of pharmacological activities, namely of anti-inflammatory, antioxidants, antimicrobial, hyperlipidemia agents, and $\alpha$-glucosidase inhibitors [1].

Therapy of diabetes mellitus with the mechanism of enzyme $\alpha$-glucosidase inhibition is one of the pharmacological activity of Garcinia plants is under development. The $\alpha$-glucosidase enzyme is a major intestinal enzyme in carbohydrate digestion. Inhibition of these enzymes can delay the process of hydrolysis of carbohydrates, which leads to prevention of excess glucose absorption in the intestine that causes a decrease in blood glucose levels so that the glycemic control can be done better [2].

Diabetes mellitus is a metabolic disease that causes hyperglycemia, due to the lack of the hormone insulin, decreasing the effects of insulin or both [3]. The prevalence of diabetes mellitus is increasing each year. International Diabetes Federation (IDF) reported that the prevalence of diabetes mellitus in 2015 with an age range 20-79 years in Indonesia has ranked $7^{\text {th }}$ with about 10.0 million patients. IDF also stated in 2040 is estimated prevalence will continue to increase, which ranked $6^{\text {th }}$ with 16.2 million people [4]. Hence, the search for active compounds continues to be done.

Some plants of Garcinia species have been studied scientifically and are known to have activity as an antidiabetic, among others Garcinia brevipedicellata [5], Garcinia mangostana [6], Garcinia nobilis [7], and Garcinia hanburyi [8]. The bioactive compounds that play a role in the $\alpha$-glucosidase inhibitor from each of these plants that brevipsidones D, prenylated xanthones, xanthones, and polyprenylated xanthones [5-8].

The Garcinia kydia Roxb. is one species of the family Clusiaceae. In a previous study, the $80 \%$ ethanol extracts of leaves has activity against $\alpha$-glucosidase inhibition with inhibitory concentration $\left(\mathrm{IC}_{50}\right)$ values of $3.88 \mathrm{mg} / \mathrm{ml}$. Chemical constituents that have been identified, namely, flavonoids, terpenoids, tannins, glycosides, saponins, and anthraquinone [9]. In preliminary testing of secondary metabolites were reported, n-hexane extracts have to contain the steroid/terpenoids, the ethyl acetate extract contains alkaloids, flavonoids, steroids/terpenoids, while the methanol extract contains alkaloids, flavonoids, tannins, anthraquinone, and saponin [10]. However, activity against $\alpha$-glucosidase inhibition in the extracts and fraction of methanol (FMT), ethyl acetate (FEA) and n-hexane extracts from leaves of G. kydia Roxb. has not been reported.

In this study, reported differences in the strength of activity against $\alpha$-glucosidase inhibition conducted of in vitro with measuring the quantity using the microplate reader from various extracts leaves of G. kydia Roxb., as well as evaluating the activity of the active fraction of the extract of potentially have $\alpha$-glucosidase inhibitory activity, which compared to standard acarbose and identify the compound from the active fraction with normal-phase thin layer chromatography (TLC).

\section{METHODS}

\section{Collection of plant and extract}

The test plants are from the collection of plants Bogor Botanical Gardens in November 2011 and have been identified in the Center for Plant Conservation Indonesian Institute of Sciences, Bogor, Indonesia. The 
G. kydia Roxb. leaves extract of n-hexane, ethyl acetate, and methanol obtained from Phytochemistry Research Laboratory of the Faculty of Pharmacy, University of Indonesia.

\section{Fractionation processing}

The ethyl acetate and methanol leaves extracts of G. kydia Roxb. fractionated by column chromatography using silica gel 60 as stationary phase (230-400 mesh, Merck) [11,12]. The mobile phase is a mixture of the solvent (all the solvents were distilled before being used) with certain ratio, that the obtained gradient eluent system with different polarity. Elution process using solvent mixture of low to high polarity (n-hexane - ethyl acetate - methanol) The fractions have been obtained is then evaporated and the chromatogram profiles identified by the method of TLC using silica gel $60 \mathrm{~F}_{254}$ (Merck, 0,25 mm, normal phase) $[13,14]$. So that the fraction that has the same of chromatogram profile, then combined and conducted of testing the inhibitory activity of the $\alpha$-glucosidase enzyme.

\section{Determination of the inhibitory activity of $\alpha$-glucosidase}

The inhibitory activity of a-glucosidase was specified using the methods of publications that have been modified [15]. $5 \mathrm{mg}$ of $\alpha$-glucosidase solid dissolved in a solution of phosphate buffer $\mathrm{pH} 6.8\left(\mathrm{KH}_{2} \mathrm{PO}_{4} 0.2\right.$ $\mathrm{M}$ and $\mathrm{NaOH} 0.2 \mathrm{M}$ solution, Merck) which already contains $0.2 \%$ bovine serum albumin (Sigma-Aldrich, USA) sufficient to $1.0 \mathrm{ml}$ in low temperature conditions $\left(2-8^{\circ} \mathrm{C}\right)$.

The reaction solution containing $30 \mu \mathrm{l}$ of the sample with different concentrations was added to $36 \mu \mathrm{l}$ of phosphate buffer $\mathrm{pH} 6.8$ and $17 \mu \mathrm{l}$ of $4 \mathrm{mM}$ p-nitrophenyl $\alpha$-D-glucopyranoside (p-NPG) (Sigma-Aldrich, Switzerland) as a substrate. Then, the solution was incubated for 5 minutes at $37^{\circ} \mathrm{C}$, and after incubation, the solution was added $17 \mu$ l solution of $\alpha$-glucosidase (Sigma-Aldrich, Germany) 0.08 Units $/ \mathrm{ml}$. The solution in incubation return at $37^{\circ} \mathrm{C}$ for 15 minutes. After that, the reaction is terminated by addition of $100 \mu \mathrm{l}$ sodium carbonate (Merck) $267 \mathrm{mM}$.

The inhibitory activity of a-glu cosidase was determined at a wavelength of $400 \mathrm{~nm}$ with molecular devices spectrophotometer (Microplate reader, VersaMax tunable) by measuring the quantity of product p-nitrophenol resulting from the process hydrolysis of p-NPG [16]. Acarbose (Sigma-Aldrich, USA) can be used as a standard the $\alpha$-glucosidase inhibitor [17].

\section{Statistical analysis of data}

The activity of $\alpha$-glucosidase inhibitory in each extract and fraction is defined as the Percentage of enzyme inhibition of each extract and fraction was calculated as follows:

$\%$ Inhibition $=\frac{\mathrm{C}-\mathrm{S}}{\mathrm{C}} \times 100 \%$

Where $\mathrm{C}$ represents the difference between the blank absorbance and control blank absorbance, and S represents the difference between the sample absorbance and control sample absorbance.

The activity of $\alpha$-glucosidase inhibitory in the active fraction is defined as the difference between the $\mathrm{IC}_{50}$, concentration that could inhibit the activity of $\alpha$-glucosidase at $50 \%$ ) of the active fraction and compared to acarbose as standard, determined by statistically analysis using GraphPad Prism for Windows version 7.0, with the following non-linear regression from equation of three-parameter logistic (GraphPad Software) [18].

\section{Identification of compounds with TLC}

The fraction of potentially inhibit $\alpha$-glucosidase were identified with TLC method $[13,19]$ using stationary phase and mobile phase of silica gel 60 $\mathrm{F}_{254}$ and chloroform:ethyl acetate:formic acid (1:1:0.5), respectively. The spots were detected with ultraviolet lamp at 254; by spraying reagent with $\mathrm{AlCl}_{3}$ followed by heating. Thus obtained chromatographic profile.

\section{RESULT AND DISCUSSION}

\section{Screening of activities extracts and fractionation}

Screening is done by comparing the strength of $\alpha$-glucosidase inhibitory activity of the n-hexane, ethyl acetate and methanol extract of leaves of G. kydia Roxb. at concentrations of 500 and $50 \mu \mathrm{g} / \mathrm{ml}$ which is described by percent inhibition. The results showed that of the three extracts that could potentially have activity in inhibiting the $\alpha$-glucosidase of an extract of ethyl acetate and methanol, a summary is presented in Table 1.

The ethyl acetate and methanol extract that could potentially, further fractionation by column chromatography method and successively are eluted using the eluent increased of polarity, so that the compound contained in the extract can be separated well by of polarity. The results of fractionated by column chromatography on ethyl acetate and methanol extracts with two stages of identification using TLC led to respectively of 14 fractions and 19 fractions.

\section{$\alpha$-glucosidase inhibitory potential of extracts, fractions, and the} active fraction

The enzyme activity can be demonstrated by the change in color of the substrate, caused by the hydrolysis process of the substrate by the $\alpha$-glucosidase enzyme to be the color of the product (p-nitrophenol and $\alpha$-D-glucose). The color change can then be determined quantitatively by measuring the absorbance of p-nitrophenol at a wavelength of $400 \mathrm{~nm}$ by microplate reader. If the inhibitor can inhibit the activity of $\alpha$-glucosidase, then the p-nitrophenol formed will be reduced [20].

Fractions obtained from the FEA and FMT extract, were tested for inhibitory activity of $\alpha$-glucosidase at a concentration of $100 \mu \mathrm{g} / \mathrm{ml}$, so that the active fraction from both extracts, namely, fraction 8 (FEA) and 3 (FMT) with the percentage inhibition of $80 \%$ and $71 \%$, a summary is shown in Tables 2 and 3.

The examination of $\alpha$-glucosidase inhibitory activity on of the active fraction with different concentrations of $250,200,100,50,12.5$, and $6,25 \mu \mathrm{g} / \mathrm{ml}$ to obtain the $\mathrm{IC}_{50}$ value of $2.79 \mu \mathrm{g} / \mathrm{ml}$ (FEA8) and $8.43 \mu \mathrm{g} / \mathrm{ml}$ (FMT3), the active fraction has $\mathrm{IC}_{50}$ values lower than acarbose $(39.5 \mu \mathrm{g} / \mathrm{ml})$. A summary is shown in Tables 4 and 5 . This is because the chemical compounds from the fraction is not purified further, so the possibility of a synergistic effect in the inhibition of $\alpha$-glucosidase

\section{Identification of compounds with TLC}

Based on the identification of ethyl acetate and methanol extracts of leaves G. kydia Roxb. using TLC to obtain a chromatogram profile with yellow spots, which indicate the presence of flavonoid compounds [21]. In this study, the identification of compounds against the active FEA

Table 1: Comparison of inhibitory activity against $\alpha$-glucosidase on the extracts with different solvents

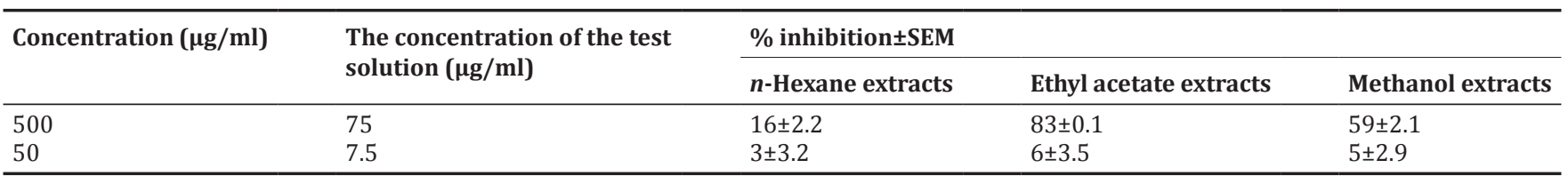

$\%$ inhibition values expressed as SEM: Standard error of mean, where $n=3$ 
and FMT using the eluent chloroform:ethyl acetate:formic acid (1:1:0.5) obtained some yellow and blue spot indicated of flavonoid compounds, this is because the reaction $\mathrm{AlCl}_{3}$ with the keto group in the $\mathrm{C} 4, \mathrm{C} 5$ and $\mathrm{OH}$ group on ortho position of flavonoid compounds to form a complex compound of yellow, chromatogram profiles shown in Fig. 1.

Based on the literature of flavonoid compounds potentially useful in the inhibition of $\alpha$-glucosidase [22]. Identification of these compounds can be used as data for further research in the isolation of compounds that

Table 2: Comparison of inhibitory activity against $\alpha$-glucosidase of the fractions of ethyl acetate with a concentration of $100 \mu \mathrm{g} / \mathrm{ml}$ (concentration in the test solution $15 \mu \mathrm{g} / \mathrm{ml}$ )

\begin{tabular}{ll}
\hline Fraction & \% inhibition $\mathbf{S E M}$ \\
\hline 1 & $7 \pm 1.6$ \\
2 & $3 \pm 1.9$ \\
3 & $12 \pm 5.5$ \\
4 & $9 \pm 0.9$ \\
5 & $10 \pm 2.1$ \\
6 & $11 \pm 5.1$ \\
7 & $75 \pm 2.8$ \\
8 & $80 \pm 1.7$ \\
9 & $55 \pm 7.7$ \\
10 & $38 \pm 1.3$ \\
11 & $33 \pm 0.9$ \\
12 & $15 \pm 2.1$ \\
13 & $12 \pm 0.9$ \\
\hline
\end{tabular}

$\%$ inhibition values expressed as SEM: Standard error of mean, where $n=3$

Table 3: Comparison of inhibitory activity against $\alpha$-glucosidase of the fractions of methanol at a concentration of $100 \mu \mathrm{g} / \mathrm{ml}$ (concentration in the test solution $15 \mu \mathrm{g} / \mathrm{ml}$ )

\begin{tabular}{ll}
\hline Fraction & \% inhibition \pm SEM \\
\hline 1 & $37 \pm 4.6$ \\
2 & $27 \pm 2.6$ \\
3 & $71 \pm 3.5$ \\
4 & $60 \pm 1.9$ \\
5 & $47 \pm 1.5$ \\
6 & $40 \pm 5.6$ \\
7 & $18 \pm 0.3$ \\
8 & $20 \pm 0.2$ \\
9 & $36 \pm 4.9$ \\
10 & $29 \pm 4.6$ \\
11 & $22 \pm 1.3$ \\
12 & $18 \pm 0.7$ \\
13 & $18 \pm 0.7$ \\
14 & $23 \pm 0.5$ \\
15 & $23 \pm 1.4$ \\
16 & $28 \pm 0.9$ \\
17 & $21 \pm 3.2$ \\
18 & $27 \pm 3.1$ \\
19 & $27 \pm 3.8$ \\
\hline
\end{tabular}

$\%$ inhibition values expressed as SEM: Standar error of mean, where $n=3$ potentially the inhibition of $\alpha$-glucosidase (Fig.2).

\section{CONCLUSION}

The comparison of $\alpha$-glucosidase inhibitory activity of leaves extract of $G$. kydia Roxb, obtained the extracts that could potentially inhibit the $\alpha$-glucosidase, which ethyl acetate and methanol extracts. The comparison the inhibitory between fractions with a concentration of $100 \mu \mathrm{g} / \mathrm{ml}$ for each fraction, thus obtained the active FEA8 and FMT3. The active fraction has stronger activity compared to acarbose, this is indicated by $\mathrm{IC}_{50}$ values are generated by the active FEA and FMT is

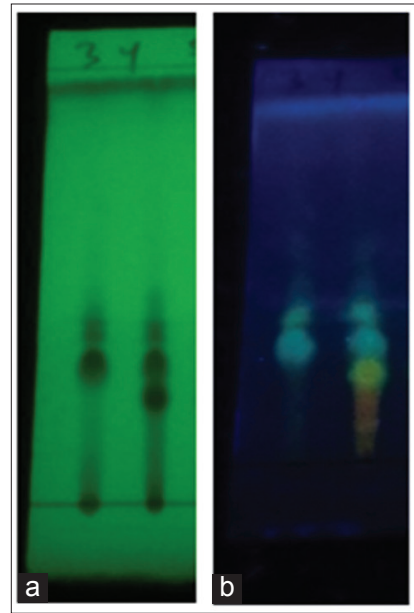

Fig. 1: Chromatography profile of the active fraction of methanol (FMT3 and FMT4) detected by ultraviolet lamp 254 (a) and the spray reagent $\mathrm{AlCl}_{3}$ (b)
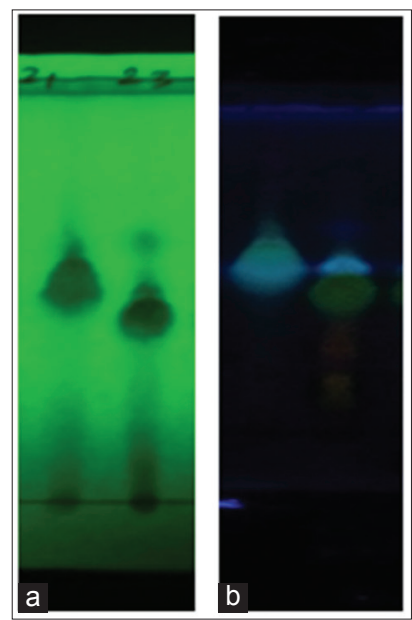

Fig. 2: Chromatography profile of the active fraction of ethyl acetate (FEA8 and FEA9) detected by ultraviolet lamp 254 (a) and the spray reagent $\mathrm{AlCl}_{3}$ (b)

Table 4: $\alpha$-glucosidase inhibitory potential of the active FEA and FMT

\begin{tabular}{|c|c|c|c|c|c|}
\hline \multirow[t]{2}{*}{ Concentration $(\mu \mathrm{g} / \mathrm{ml})$} & \multirow{2}{*}{$\begin{array}{l}\text { The concentration of the test } \\
\text { solution }(\mu \mathrm{g} / \mathrm{ml})\end{array}$} & \multicolumn{2}{|l|}{ FEA8 } & \multicolumn{2}{|l|}{ FMT3 } \\
\hline & & $\%$ inhibition \pm SEM & $\mathrm{IC}_{50}(\mu \mathrm{g} / \mathrm{ml})$ & $\%$ inhibition \pm SEM & $\mathrm{IC}_{50}(\mu \mathrm{g} / \mathrm{ml})$ \\
\hline 250 & 37.5 & $92 \pm 1.4$ & 2.79 & $97 \pm 0.4$ & 8.43 \\
\hline 100 & 15.0 & $80 \pm 0.7$ & & $78 \pm 2.8$ & \\
\hline 50 & 7.50 & $59 \pm 1.5$ & & $56 \pm 3.7$ & \\
\hline 12.5 & 1.875 & $40 \pm 4.2$ & & $18 \pm 3.5$ & \\
\hline 6.25 & 0.9375 & $8 \pm 2.2$ & & $15 \pm 2.4$ & \\
\hline
\end{tabular}

$\%$ inhibition values expressed as SEM: Standard error of mean, where $\mathrm{n}=3$, IC $\mathrm{C}_{50}$. Inhibitory concentration $50 \%$ 
Table 5: Summary of $\mathrm{IC}_{50}$ values the fraction FEA8 and FMT3

\begin{tabular}{lr}
\hline $\mathbf{I C}_{\mathbf{5 0}}$ values $(\boldsymbol{\mu g} / \mathbf{m l})$ & \\
\hline FEA8 & 2.79 \\
FMT3 & 8.43 \\
Acarbose (Standard compound) & 39.5 \\
\hline IC $_{50}:$ Inhibitory concentration $50 \%$ &
\end{tabular}

smaller than acarbose. The active fractions of FEA8 and FMT3 were identified compound, thus acquired chromatogram profile suspected of flavonoid and phenolic compounds. Identification of these compounds can be used as a source of information, so that later can be developed for further research in isolating active compounds that play a role in the inhibition of $\alpha$-glucosidase, thus acquired natural therapeutic agents that can control blood glucose so as to improve the quality of life of patients with diabetes mellitus.

\section{ACKNOWLEDGMENTS}

The author would like to thank PUPT Grant 2016 the opportunity research given. We would like to thank technical staff of the Research Laboratory of Phytochemistry and Laboratory of Quantitative Chemical Analysis, Faculty of Pharmacy at the University of Indonesia, Depok who have helped in the implementation of the research described in this manuscript.

\section{REFERENCES}

1. Hemshekhar M, Sunitha K, Santhosh MS, Devaraja S, Kemparaju K, Vishwanath BS, et al. An overview on genus Garcinia: Phytochemical and therapeutical aspects. Phytochem Rev 2011;10:325-51.

2. Kalra S. Alpha glucosidase inhibitors. J Pak Med Assoc 2014;64(4):474-6.

3. American Diabetes Association. Diagnosis and classification of diabetes mellitus. Diabetes Care 2004;27 Suppl 1:S5-10.

4. International Diabetes Federation (IDF). Diabetes Atlas. $7^{\text {nd }}$ ed. Europe: IDF; 2015. p. 52.

5. Ngoupayo J, Tabopda TK, Ali MS, Tsamo E. Alpha-glucosidase inhibitors from Garcinia brevipedicellata (Clusiaceae). Chem Pharm Bull (Tokyo) 2008;56(10):1466-9.

6. Ryu HW, Cho JK, Curtis-Long MJ, Yuk HJ, Kim YS, Jung S, et al. A-glucosidase inhibition and antihyperglycemic activity of prenylated xanthones from Garcinia mangostana. Phytochemistry 2011;72(17):2148-54.

7. Fouotsa H, Lannang AM, Mbazoa CD, Rasheed S, Marasini BP, Ali Z, et al. Xanthones inhibitors of $\alpha$-glucosidase and glycation from Garcinia nobilis. Phytochem Lett 2012;5(2):236-9.
8. Chen Y, He S, Tang C, Li J, Yang G. Caged polyprenylated xanthones from the resin of Garcinia hanburyi. Fitoterapia 2016;109:106-12.

9. Elya B, Basah K, Mun'im A, Yuliastuti W, Bangun A, Septiana EK. Screening of a-glucosidase inhibitory activity from some plants of Apocynaceae, Clusiaceae, Euphorbiaceae, and Rubiaceae. J Biomed Biotechnol 2012;2012:281078.

10. Elya B, Katrin B, Mun'im A, Hasiholan A, Marlin I, Mailandari M. Antioxidant activities of leaves extracts of three species of Garcinia. Int J Med Aromat Plants 2012;2(4):691-3.

11. Ahmad I, Lestari R. Isolasi antioksidan tumbuhan sarang semut (Myrmecodia pendens Merr and Perry) asal Papua. J Trop Pharm Chem 2011;1(3):199-204.

12. Meechai I, Phupong W, Chunglok W, Meepowpan P. Anti-radical activities of xanthones and flavonoids from Garcinia schomburgkiana. Int J Pharm Pharm Sci 2016;8(9):235-8.

13. Ahmad I, Arifuddin M, Rijai L. The effect of extraction methods of bawang dayak (Eleutherine palmifolia L. MERR) against TLC profiles and sunscreen activities. Int J Pharmtech Res 2016;9(9):428-36.

14. Bhardwaj A, Modi KP. Pharmacognostical screening and determination of antioxidant activity of Nelumbo nucifera gaertn ethanol seed extract by different in vitro models. Int J Pharm Pharm Sci 2017;9(3):64-70.

15. Elya B, Handayani R, Sauriasari R, Azizahwati, Hasyyati US, Permana IT, et al. Antidiabetic activity and phytochemical screening of extracts from Indonesias plants by inhibition of alpha amylase, alpha glucosidase and dipeptidyl peptidase IV. Pak J Biol Sci 2015;18(6):279-84.

16. Lestari Y, Velina Y, Rahminiwati M. Metabolites activity of endophytic Streptomyces SP. IPBCC. B.15.1539 from Tinospora crispa L. Miers: $\alpha$-glucosidase inhibitor and anti-hyperglycemic in mice. Int J Pharm Pharm Sci 2015;7(6):235-9.

17. Okoro IO, Umar IA, Atawodi SE, Anigo KM. In vitro and in vivo antihyperglycemic effect of active fraction of Cleome rutidosperma DC. Int J Pharm Pharm Sci 2015;7(1):289-95.

18. Annan K, Sarpong K, Asare C, Dickson R, Amponsah KI, Gyan B, et al. In vitro anti-plasmodial activity of three herbal remedies for malaria in Ghana: Adenia cissampeloides (Planch.) Harms., Termina liaivorensis A. Chev, and Elaeis guineensis Jacq. Pharmacogn Res 2012;4(4):225-9.

19. Ahmad I, Yanuar A, Mulia K, Mun'im A. Application of ionic liquid based microwave-assisted extraction of the secondary metabolite from Peperomia pellucida (L) Kunth. Pharmacogn J 2017;9(2):227-34.

20. Méndez-Vilas A. Current Research, Technology and Education Topics in Applied Microbiology and Microbial Biotechnology. Ch. 87. Badajoz, Spain: Formatex Research Center; 2010. p. 945-55.

21. Putri NL, Elya B, Puspitasari N. Antioxidant activity and lipoxygenase inhibition test with total flavonoid content from Garcinia kydia roxburgh leaves extract. Pharmacogn J 2017;9(2):280-4

22. Tadera K, Minami Y, Takamatsu K, Matsuoka T. Inhibition of alphaglucosidase and alpha-amylase by flavonoids. J Nutr Sci Vitaminol (Tokyo) 2006;52(2):149-53. 